\title{
ANDROGEN RECEPTORS: UNCLEAR UBIQUITIOUS MECHANISM OR THE MISSING KEY IN THE TRIPLE-NEGATIVE BREAST CANCER?
}

\author{
ANA TEČIĆ VUGER ${ }^{1}$, ROBERT ŠEPAROVIĆ ${ }^{1,4}$, LJUBICA VAZDAR ${ }^{1}$, MIRJANA PAVLOVIĆ ${ }^{1}$, \\ PETRA LEPETIĆ ${ }^{1}$, SANDA ŠITIĆ ${ }^{2}$, BOŽENA ŠARČEVIĆ ${ }^{3}$ and DAMIR VRBANEC ${ }^{4}$ \\ ${ }^{1}$ Medical Oncology Department, Division for Radiotherapy and Medical Oncology, \\ University Hospital for Tumors, Sestre milosrdnice University Hospital Center, Zagreb, Croatia; \\ ${ }^{2}$ Department of Oncological Pathology and Clinical Cytology, Ljudevit Jurak University Department \\ of Pathology, Sestre milosrdnice University Hospital Center, Zagreb, Croatia; \\ ${ }^{3}$ School of Medicine, University of Zagreb, Zagreb, Croatia; \\ ${ }^{4}$ Medical School, University of Juraj Dobrila, Pula, Croatia
}

\begin{abstract}
Summary
Androgen receptors (AR) are ligand-dependent nuclear transcription factors. These are steroid receptors, similar to estrogen receptors (ER). They are expressed in numerous cells in the body, with different constructive roles. AR signalling can be involved in the development of a variety of human malignant tumors, such as prostate cancer, bladder, liver, salivary glands, kidney, lung, melanoma, sarcoma, breast cancer, and many others. The role of AR is most clear and today best explained in prostate cancer. The mechanism of AR signalling in other human epithelial tumors is still quite unclear and the effects are different to entirely opposite in different tumors. In breast cancer, AR are the most commonly expressed receptors, but still with an incompletely clear role, prognostic and predictive significance. The expression of AR in triple-negative breast cancer (TNBC) is highly variable. Despite the marked differences in the results of the various analyzes, they appear to have a beneficial effect on the prognosis and are potentially the target of antihormone therapy for treatment of TNBC in the future.
\end{abstract}

KEY WORDS: androgen receptors, prostate cancer, breast cancer, triple-negative breast cancer

\section{STRUCTURE AND FUNCTION OF ANDROGEN RECEPTORS}

Androgen receptors (AR) are ligand-dependent nuclear transcription factors, which control the expression of specific genes and by which the action of androgens (testosterone and dihydrostestosterone) in the body takes place. They belong to the steroid hormone nuclear receptor

Corresponding author: Ana Tečić Vuger, Department of Medical Oncology, Division for Radiotherapy and Medical Oncology, University Hospital for Tumors, Sestre milosrdnice University Hospital Center, Ilica 197, 10000 Zagreb, Croatia.

e-mail:ana.tecic@yahoo.com families, along with estrogen (ER), progesterone $(\mathrm{PR})$, glucocorticoid (GR), and mineralocorticoid receptors (MR). They are expressed in numerous cells and tissues and have different roles, such as those in the construction and maintenance of the sexual, musculoskeletal, circulatory, immune, nervous and hematopoietic system.

AR is one polypeptide, consisting of three main domains: $\mathrm{N}$ - terminal domains for transcription regulation, DNA binding domain (DBD), ligand binding domain (LBD) and the hinged region, which connects DBD and LBD $(1,2)$. AR activity occurs through a ligand-dependent transcriptional activation function and a ligand-in- 
dependent transcriptional activation function. Ligand-dependent transcriptional activation functions are linked to LBD and differentiate between different nuclear hormone steroid receptors. There are two ways in which these ligand-dependent functions of AR occur. The first form is a DNAdependent form of AR activity, called the genomic, classical, or canonical form of AR function. In the absence of ligands, AR are found in the cytosol of the cell, bound by heat - schock and other chaperons. Androgen (ligand) binding induces conformational changes, dissociation of bound cytosolic proteins for $\mathrm{AR}$, and transfer of the AR ligand complex to the nucleus, where it dimerizes and binds to selective ARE (Androgen response elements) in target genes, which modulate the transcription process. Transcriptional activity of the AR - androgen complex is also modulated by specific protein - CO - regulators, which, by binding to activated AR, enhance or suppress the transcription process. $(1,2)$ Another form of ligand-dependent function of AR is DNA-independent form, also called non-genome, non-classical, or non-canonical form of AR function, whereby alternative signaling pathways such as ERK/Akt and MAPK are triggered within moments of androgen binding to the receptor, which is too fast to generate a signaling cascade via DBD, by DNA binding, to regulate the transcriptional and translational processes. In addition, other alternative signaling and indirect regulation pathways of transcription and translation processes that occur in DNA-independent AR binding function have been explored, and these mechanisms have been observed in a number of different cells, however, studies of this mechanism remain at in vitro study, with no clear answer as to their exact physiological significance. The ligand-independent activities of AR are triggered by a number of different growth factors, and through phosphorylation of AR or interaction with coactivators, they ultimately affect transcription and translation processes.

An example of such an AR mechanism of action is the IL - 6 pathway, which activates AR via protein kinase A (PKA), protein kinase C (PKC) and the MAPK signaling pathway. Such mechanisms have been observed and are of clinical importance in prostate cancer $(1,2,3)$. Glutamine repeats (CAGs) occur in the $\mathrm{N}$ - terminal transactivation domain (NTD) in the AR composition and the number of these repeats is variable, resulting in variations in all amino acids in the AR composition. Shorter glutamine repeats are associated with a stronger transcriptional activity of AR, which also increases the risk of malignant alteration, which has been observed in men who are more likely to have prostate cancer (1-3).

\section{THE ROLE OF ANDROGEN RECEPTORS IN HUMAN MALIGNANT TUMORS}

AR signalling can be involved in the development of a variety of human malignant tumors, such as prostate cancer, bladder, liver, salivary glands, kidney, lung, melanoma, sarcoma, breast cancer, and many others (4). The role of AR in prostate cancer is much clearer and better explained today than AR signaling in other human epithelial tumors (3). However, it is known today that signaling via steroid receptors is often associated with the development and progression of the disease, in a number of these cancers. The exact mechanism by which AR signaling participates in the promotion, development, and progression of bladder cancer is still unknown, however, sure role of $\mathrm{AR}$ in carcinogenesis may explain the differences observed between men and women with urothelial cancer, and they place this tumor in the category of hormone-dependent tumors (5).

The expression of AR in most ductal variants of salivary gland tumors, which are known to be less responsive to chemotherapy, may in the future allow the treatment of these tumors with antihormonal therapy (6).

Hepatocellular carcinoma, pancreatic cancer and their surrounding tissues to some extent express AR, and AR itself, not including androgens, appears to play a role in the carcinogenesis and development of these tumors and make potentially interesting therapeutic targets (7).

The presence of AR in malignant melanoma cells supports metastatic potential and affects the development of distant metastases (8). On the other hand, the presence of AR in cells of clear cell or papillary kidney cancer seems to be associated with better clinical course and prognosis of the disease (9).

Differences in the course of the disease and the prognosis of lung cancer between men and women have suggested the influence of steroid hormones and numerous studies have demon- 
strated the effect of ER, PR or AR, although often contradictory (10).

Today we still do not have a definitive answer about the role of AR in some of the tumors studied, the results of the studies conducted so far are often contradictory, and more detailed analyzes and model work, such as ARKO (AR knock out) mice show how AR actually have different effects on different cell lines, even in the same tumor (11).

Further studies are needed to undoubtedly define the position of AR in the tumorigenesis, metastasizing and prognosis of certain hormonedependent malignancies, and the most relevant data are currently available in prostate cancer and breast cancer $(\mathrm{BC})$.

\section{ANDROGEN RECEPTORS IN PROSTATE CANCER}

The impact of androgens on the growth and survival of prostate cancer cells has long been known. Androgen deprivation therapy (ADT) is now the backbone of treatment in advanced, and also shows success in the treatment of high-risk early prostate cancer. Androgens and AR are the basic regulators of the cell proliferation-death ratio, on which the continued growth and survival of the prostate tumor depends (12).

Activation of various growth-promoting signaling pathways plays a role in the development of prostate cancer. Such is also the androgen-dependent up-regulation of transcription factors belonging to the ETS family, which happens by fusion of the AR-regulated TMPRSS2 promoter gene and the coding region of the ERG and ETV1 genes, members of the ETS family. The process is managed by AR, who are thus responsible for transcription, leading to cell cycle progression. The described mechanism occurs in about $50 \%$ of prostate cancer cases (13).

In addition, other signaling pathways are active in prostate cancer, such as PI3K and RAS / RAF, dysregulation of which has been observed in both early and advanced stages of prostate cancer (14), but most studies indicate significant alterations in the AR signaling pathway, over all others, and therefore this mechanism remains a key regulator of prostate cancer pathogenesis. Therefore the rationale to use androgen suppression methods in the treatment of prostate cancer. Initial treat- ment is based on the idea of complete androgen blockade: conventional ADT is achieved by AR deprivation by removing testosterone generated in the testes, either by surgical or chemical (GnRH analogs) orchidectomy, to which therapy with AR antagonists/ antiandrogens is often added (15). Such androgen blockade is not conclusive and over time, castration-resistant prostate cancer (CRPC) develops, when the disease no longer responds to androgen-deprivation therapy methods.

Several mechanisms have been shown to underpin CRPC development: point mutations of $A R$, amplification of $A R$, changes in androgen biosynthesis, changes in AR cofactors, variations of AR (3). In most cases it happens through AR overexpression associated with continuous tumor steroidogenesis, binding and activation of AR by alternative ligands, such as estrogen and progesterone, glucocorticoids and flutamide, by ligandindependent mechanisms of AR activation by interacting with Akt, HER2 and Ack1 kinases that phosphorylate AR and with non-coding RNAs that bind to AR to stimulate transcription of target genes or, to a lesser extent, AR-independent pathways via Stat3 signaling or up-regulation of antiapoptotic Bcl-2 (2). The mechanisms described indicate a key role for $\mathrm{AR}$ in both the development of CRPC and the development of resistance to AR directed therapy.

\section{ANDROGEN RECEPTORS IN BREAST CANCER}

AR are the most commonly expressed hormone receptors in $\mathrm{BC}$ and over $70 \%$ of all $\mathrm{BC}$ have positive AR (16). However, despite decades of research into AR in various BC subtypes, their role as an independent predictive and prognostic factor has not been clearly defined to date, and therefore the clinical significance is still incompletely understood today. AR are expressed in two types of mammary epithelial cells: mostly uniformly and diffusely in metaplastic apocrine cells and in about 5 to $30 \%$ of normal luminal epithelial cells, without apocrine differentiation. They are therefore most commonly expressed in the apocrine and lobular histological type of breast cancer, and are least expressed in the metaplastic, mucinous, and medullary types. They are more frequently present in luminal, ER positive breast cancers and 
are strongly correlated with ER and PR, and less frequently present in ER negative tumors, among which they are more commonly correlated with HER2 protein expression $(17,18)$.

Preclinical studies have shown that the effect of AR in different BC cell lines can be both stimulating and inhibitory, depending on the presence or absence of ER. According to some studies, in an ER positive environment, AR is considered a tumor suppressor because it exhibits antiproliferative effects resulting from the interaction of ER and AR signaling pathways, that is, antagonizing ER activity by AR, which occurs through competitive ER knockdown and binding to ERE (Estrogen esponse elements) and formation of an inactive transcription complex, which does not progress to further transcription of targeted ER genes.

Androgen-activated AR compete with the ER for a limited amount of transcriptional coactivators, thereby inhibiting target ER genes and activating target AR genes (19). Expression of AR was observed in less aggressive forms of the disease: tumors of smaller size, lower grade, lower proliferative index, without affected lymph nodes (20). Several different studies and meta-analyzes on the role of AR in BC have shown interesting and often conflicting results. In some, AR expression in breast cancer was positively correlated with disease - free survival (DFS) and overall survival (OS) $(16,21)$, while in others, no statistically significant causal relationship was found (22).

Some studies have shown that the expression of $A R$ in $B C$ is a positive indicator and correlates with DFS and OS in ER positive tumors but not in ER negative ones $(23,24)$, while other studies have shown that it is precisely in ER negative, that is, in TNBC, that the causal correlation between the presence of AR and better DFS and OS is the highest $(25,26)$. Similar was seen in the studies that have shown that the expression of $A R$ has been correlated with the molecular subtypes of BC.

The expression of AR in relation to gender showed a significant association of AR expression with good clinical outcomes in women with BC, whereas in men there was no statistical association (22). Numerous differences in the results of the aforementioned studies are often explained by insufficient sample sizes for obtaining statistically and clinically relevant data, but also by differences in the AR evaluation methods used, as well as defined limits for AR positivity $(16,21-26)$.
In the sense of predictivity, some studies suggest an association of AR with better response to antihormonal therapy, but in response to chemotherapy AR positive tumors, regardless of the expression of other receptors (ER, PR, HER2), appear to retain luminal tumor behavior and lower rates can be expected in the response (27).

AR were recognized as a therapeutic target in breast cancer long before the discovery of tamoxifen and aromatase inhibitors, and steroidal androgens were unselectively used in BC therapy until, owing to their significant toxic profile (virilization and other masculinizing effects), they were replaced by the arrival of new endocrine therapies.

The results of preclinical studies show mainly antiproliferative effects of androgens on ER and AR positive tumor cell lines and indicate that AR agonists could be a logical therapeutic choice in luminal BC (28).

At the clinical level, as mentioned, there is historical evidence of efficacy over half a century, but few controlled clinical studies are available, and it is therefore not entirely clear which subtypes would best respond to androgens and to what extent, and what therapeutic combinations, with other active agents, would be the right ones (29).

Studies with newer non-steroidal selective AR modulators (SARMs) and nonsteroidal androgens, such as the phase II study with enobosarm (NCT02463032), are underway to answer some of these questions.

\section{ANDROGEN RECEPTORS IN TRIPLE-NEGATIVE BREAST CANCER}

The expression of $\mathrm{AR}$ in TNBC, according to various studies, is highly variable, but the share of about $25-35 \%$ of AR positive TNBC is most commonly reported (30.) According to the molecular classification of TNBC in six subgroups, the LAR subtype - luminal AR subtype, characterized by AR signaling, was identified, in which the most significant AR expression was observed, in terms of the highest percentage of AR positive tumor cells and staining intensity (31).

According to the immunohistochemical division of TNBC into the core - basal subtype (ER-, PR-, HER2-, CK5 / $6+$ and / or EGFR +) and 5NP subtype (all five markers negative) (32), studies have shown a higher prevalence of $A R$ in $5 \mathrm{NP}$ 
subtype (33). Also, almost all AR-positive TNBC exhibit morphological characteristics in the direction of apocrine differentiation and, therefore, with respect to prognostic and predictive differences, the need to distribute TNBC to the apocrine subtype, which expresses the characteristics of ER-positive tumors and nonapocrine, ductal, poorly differentiated subtype, is emphasized (18).

A positive correlation between AR expression and BRCA1 / 2 mutation was also observed and BRCA1 was considered a coactivator of the AR signaling pathway (34).

Although numerous studies on the role of AR in TNBC have been compromised by differences in methodology and defined cut-off values and often of inappropriate sample size, the results obtained to date undoubtedly indicate a prognostically favorable effect of AR expression in TNBC $(35,36)$.

While some studies have shown that there is no statistically significant positive effect of AR on survival in TNBC (24), a number of them have shown that AR expression in TNBC is an independent indicator of better DFS and OS in early TNBC $(22,37)$. The expression of AR in TNBC is associated with better clinicopathological predictive and prognostic factors. It is more common in smaller tumors, lower grade, lower proliferative index, without lymph node involvement, lower clinical stage $(24,33)$.

There was generally no difference in AR expression between early TNBC and metastatic disease, and if so, there was a trend toward lower AR expression in metastatic lesions and disease recurrence relative to the primary tumor, which is explained by the loss of AR expression in the process of metastasizing $(30,33)$. It seems that the level of intratumoral AR expression is of greater prognostic importance than the mere presence of AR itself: a worse prognosis in TNBC with decreased intratumoral AR expression was observed, and vice versa, which is explained by suppression of tumor cell proliferation by the antiproliferative effect of AR stimulation (38). In seeking biomarkers of prognostic and predictive value for TNBC, some studies have attempted to correlate $A R$ and to find common utility in combinations with other markers, such as EGFR, with which a negative correlation of AR was found (39) and E - cadherin, with which AR is positively correlated (40).
The LAR subtype TNBC, that is, the expression of $A R$ in TNBC, shows poorer rates of $\mathrm{pCR}$ on neoadjuvant chemotherapy (41). In contrast, they show good response to antihormonal therapy and so far, several clinical studies have investigated the effect of antiandrogen therapy targeting ARpositive TNBC, such as phase II studies with bicalutamide (42) and enzalutamide (43), but also a combination with new therapeutic strategies, such as PI3K inhibitors, CDK4/6 inhibitors, or mTOR inhibitors (44).

\section{CONCLUSION}

Androgen receptors are ubiquitiously found accross many human malignancies. Somewhat clearer is their role in the prostate cancer. They are definitely important, in the clinical and therapeutic manner, for the TNBC. According to AR expression there are probably two different worlds of TNBC immunophenotype. It could easily be that in the future, setting better correlation between AR expression and other molecular and hystological characteristics of TNBC together, and getting to analyze more appropriate cohorts of TNBC patients, we find a real therapeutic solution for an important cohort of patients.

\section{REFERENCES}

1. Davey RA, Grossmann M. Androgen receptor structure, function and biology: From bench to bedside. Clin Biochem Rev. 2016;37(1):3-15.

2. Tan ME, Li J, Xu HE, Melcher K, Yong E. Androgen receptor: structure, role in prostate cancer and drug discovery. Acta Pharmacol Sin. 2015;36(1):3-23.

3. Fujita K, Nonomura N. Role of androgen receptor in prostate cancer: A review. World J Mens Health. 2018;36.

4. Antonarakis E. AR Signaling in human malignancies: Prostate cancer and beyond. Cancers (Basel). 2018; 10(1):22.

5. Li P, Chen J, Miyamoto H. Androgen receptor signaling in bladder cancer. Cancers (Basel). 2017;9(12):20.

6. Dalin M, Watson P, Ho A, Morris L. Androgen receptor signaling in salivary gland cancer. Cancers (Basel). 2017;9(12):17.

7. Kanda T, Jiang X, Yokosuka O. Androgen receptor signaling in hepatocellular carcinoma and pancreatic cancers. World J Gastroenterol. 2014;20(28):9229-36.

8. Wang Y, Ou Z, Sun Y, Yeh S, Wang X, Long J, et al. Androgen receptor promotes melanoma metastasis via altering the miRNA-539-3p/USP13/MITF/AXL signals. Oncogene. 2017;36(12):1644-54. 
9. Foersch S, Schindeldecker M, Keith M, Tagscherer KE, Fernandez A, Stenzel PJ, et al. Prognostic relevance of androgen receptor expression in renal cell carcinomas. Oncotarget. 2017;8(45).

10. Berardi R, Morgese F, Santinelli A, Onofri A, Biscotti T, Brunelli A, et al. Hormonal receptors in lung adenocarcinoma: expression and difference in outcome by sex. Oncotarget. 2016;7(50).

11. Pang TPS, Clarke MV, Ghasem-Zadeh A, Lee NKL, Davey RA, MacLean HE. A physiological role for androgen actions in the absence of androgen receptor DNA binding activity. Mol Cell Endocrinol. 2012; 348(1):189-97.

12. Grossmann M, Cheung AS, Zajac JD. Androgens and prostate cancer; pathogenesis and deprivation therapy. Best Pract Res Clin Endocrinol Metab. 2013;27 (4):603-16.

13. Rubin MA, Maher CA, Chinnaiyan AM. Common gene rearrangements in prostate cancer. J Clin Oncol. 2011;29(27):3659-68.

14. Taylor BS, Schultz N, Hieronymus H, Gopalan A, Xiao Y, Carver BS, et al. Integrative genomic profiling of human prostate cancer. Cancer Cell. 2010;18(1):11-22.

15. Attard G, Parker C, Eeles RA, Schröder F, Tomlins SA, Tannock I, et al. Prostate cancer. Lancet. 2016;387 (10013):70-82.

16. Vera-Badillo FE, Templeton AJ, de Gouveia P, DiazPadilla I, Bedard PL, Al-Mubarak M, et al. Androgen receptor expression and outcomes in early breast cancer: A systematic review and meta-analysis. J Natl Cancer Inst. 2014;106(1):djt319-djt319.

17. Park S, Koo J, Park HS, Kim J-H, Choi S-Y, Lee JH, et al. Expression of androgen receptors in primary breast cancer. Ann Oncol. 2010;21(3):488-92.

18. Safarpour D, Pakneshan S, Tavassoli FA. Androgen receptor (AR) expression in 400 breast carcinomas: is routine AR assessment justified? Am J Cancer Res. 2014;4(4):353-68.

19. Peters AA, Buchanan G, Ricciardelli C, Bianco-Miotto $\mathrm{T}$, Centenera MM, Harris JM, et al. Androgen receptor inhibits estrogen receptor- Activity and is prognostic in breast cancer. Cancer Res. 2009;69(15):6131-40.

20. Collins LC, Cole KS, Marotti JD, Hu R, Schnitt SJ, Tamimi RM. Androgen receptor expression in breast cancer in relation to molecular phenotype: results from the Nurse's Health Study. Mod Pathol. 2011; 24(7):924-31.

21. Qu Q, Mao Y, Fei X, Shen K. The impact of androgen receptor expression on breast cancer survival: A retrospective study and meta-analysis. Plos One. 2013;8 (12): $\mathrm{e} 82650$.

22. Kim Y, Jae E, Yoon M. Influence of androgen receptor expression on the survival outcomes in breast cancer: A meta-analysis. J Breast Cancer. 2015;18(2):134.

23. Castellano I, Allia E, Accortanzo V, Vandone AM, Chiusa L, Arisio R, et al. Androgen receptor expression is a significant prognostic factor in estrogen receptor positive breast cancers. Breast Canc Res Treat. 2010; 124(3):607-17.

24. Hu R, Dawood S, Holmes MD, Collins LC, Schnitt SJ, Cole K, et al. Androgen receptor expression and breast cancer survival in postmenopausal women. Clin Canc Res. 2011 Apr 1;17(7):1867-74.

25. Agoff SN, Swanson PE, Linden H, Hawes SE, Lawton TJ. Androgen receptor expression in estrogen receptor-negative breast cancer immunohistochemical, clinical, and prognostic associations. Am J Clin Pathol. 2003;120(5):725-31.

26. Luo X, Shi Y-X, Li Z-M, Jiang W-Q. Expression and clinical significance of androgen receptor in triple negative breast cancer. Chin J Cancer. 2010;29(6):585-90.

27. Narayanan R, Dalton J. Androgen Receptor: A complex therapeutic target for breast cancer. Cancers (Basel). 2016;8(12):108.

28. Rahim B, O'Regan R. AR signaling in breast cancer. Cancers (Basel). 2017;9(12):21.

29. Giovannelli P, Di Donato M, Galasso G, Di Zazzo E, Bilancio A, Migliaccio A. The androgen receptor in breast cancer. Front Endocrinol (Lausanne). 2018;9.

30. Sutton LM, Cao D, Sarode V, Molberg KH, Torgbe K, Haley B, et al. Decreased androgen receptor expression is associated with distant metastases in patients with androgen receptor-expressing triple-negative breast carcinoma. Am J Clin Pathol. 2012;138(4):511-6.

31. Lehmann BD, Bauer JA, Chen X, Sanders ME, Chakravarthy AB, Shyr Y, et al. Identification of human triplenegative breast cancer subtypes and preclinical models for selection of targeted therapies. J Clin Invest. 2011;121(7):2750-67.

32. Cheang MCU, Voduc D, Bajdik C, Leung S, McKinney $\mathrm{S}$, Chia SK, et al. Basal-like breast cancer defined by five biomarkers has superior prognostic value than triple-negative phenotype. Clin Cancer Res. 2008;14 (5):1368-76.

33. Gasparini P, Fassan M, Cascione L, Guler G, Balci S, Irkkan C, et al. Androgen receptor status is a prognostic marker in non-basal triple negative breast cancers and determines novel therapeutic options. Plos One. 2014;9(2):e88525.

34. Park JJ, Irvine RA, Buchanan G, Koh SS, Park JM, Tilley WD, et al. Breast cancer susceptibility gene 1 (BRCAI) is a coactivator of the androgen receptor. Cancer Res. 2000;60(21):5946-9.

35. Astvatsaturyan K, Yue Y, Walts AE, Bose S. Androgen receptor positive triple negative breast cancer: $\mathrm{Clinico-}$ pathologic, prognostic, and predictive features. Plos One. 2018;13(6):e0197827.

36. Kucukzeybek BB, Bayoglu I V., Kucukzeybek Y, Yildız Y, Oflazoglu U, Atahan MK, et al. Prognostic significance of androgen receptor expression in HER2-positive and triple-negative breast cancer. Polish J Pathol. 2018;69(2):157-68.

37. Bozovic-Spasojevic I, Zardavas D, Brohée S, Ameye L, Fumagalli D, Ades F, et al. The prognostic role of androgen receptor in patients with early-stage breast 
cancer: A meta-analysis of clinical and gene expression data. Clin Cancer Res. 2017;23(11):2702-12.

38. McNamara KM, Yoda T, Takagi K, Miki Y, Suzuki T, Sasano H. Androgen receptor in triple negative breast cancer. J Steroid Biochem Mol Biol. 2013;133:66-76.

39. Zhang Q, Qin J, Zhong L, Gong L, Zhang B, Zhang Y, et al. CCL5-mediated Th2 immune polarization promotes metastasis in luminal breast cancer. Cancer Res. 2015;75(20):4312-21.

40. Ricciardi GRR, Adamo B, Ieni A, Licata L, Cardia R, Ferraro G, et al. Androgen receptor (AR), E-cadherin, and $\mathrm{Ki}-67$ as emerging targets and novel prognostic markers in triple-negative breast cancer (TNBC) patients. PloS One. 2015;10(6):e0128368.

41. Masuda H, Baggerly KA, Wang Y, Zhang Y, GonzalezAngulo AM, Meric-Bernstam F, et al. Differential re- sponse to neoadjuvant chemotherapy among 7 triplenegative breast cancer molecular subtypes. Clin Canc Res. 2013;19(19):5533-40.

42. Gucalp A, Tolaney S, Isakoff SJ, Ingle JN, Liu MC, Carey LA, et al. Phase II trial of bicalutamide in patients with androgen receptor-positive, estrogen receptornegative metastatic breast cancer. Clin Canc Res. 2013;19(19):5505-12.

43. Traina TA, Miller K, Yardley DA, Eakle J, Schwartzberg LS, O'Shaughnessy J, et al. Enzalutamide for the Treatment of androgen receptor-expressing triple-negative breast cancer. J Clin Oncol. 2018 36(9): 884-90.

44. Rampurwala M, Wisinski KB, O'Regan R. Role of the androgen receptor in triple-negative breast cancer. Clin Adv Hematol Oncol. 2016;14(3):186-93.

Sažetak

\begin{abstract}
ANDROGENSKI RECEPTORI: NEJASAN SVEPRISUTAN MEHANIZAM ILI KLJUČ KOJI NEDOSTAJE U TROSTRUKO NEGATIVNOM RAKU DOJKE?
\end{abstract}

\title{
A. Tečić Vuger, R. Šeparović, Lj. Vazdar, M. Pavlović, P. Lepetić, S. Šitić, B. Šarčević and D. Vrbanec
}

Androgenski receptori (AR) su jezgrini prepisivački čimbenici ovisni o ligandu. To su steroidni receptori, slični estrogenskim receptorima (ER). Izraženi su u brojnim stanicama s različitim gradivnim ulogama. AR signalizacija može biti uključena u razvoj različitih zloćudnih tumora, poput raka prostate, mokraćnog mjehura, jetre, žlijezda slinovnica, bubrega, pluća, melanoma, sarkoma, raka dojke i mnogih drugih. Uloga AR najjasnija je i najbolje objašnjena u raku prostate. Mehanizam AR signalizacije u drugim humanim epitelnim tumorima još je uvijek nejasan i učinci su kod različitih tumora različiti, sve do potpuno oprečnih. U raku dojke AR su najčešće izraženi receptori, ali još uvijek s nepotpuno jasnom ulogom, prognostičkim i prediktivnim značajem. Izraženost AR u trostruko negativnom raku dojke (TNBC) vrlo je varijabilna. Unatoč izraženim razlikama u rezultatima različitih analiza, čini se da blagotvorno utječu na prognozu i potencijalna su meta antihormonske terapije za liječenje TNRD u budućnosti.

KLJUČNE RIJEČI: androgenski receptori, rak prostate, rak dojke, trostruko negationi rak dojke 